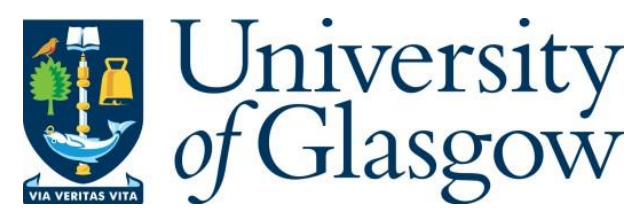

Last, A. (2017) Re-reading worldliness: Hannah Arendt and the question of matter. Environment and Planning D: Society and Space, 35(1), pp. 72-87.

There may be differences between this version and the published version. You are advised to consult the publisher's version if you wish to cite from it.

http://eprints.gla.ac.uk/171530/

Deposited on: 28 June 2020

Enlighten - Research publications by members of the University of Glasgow http://eprints.gla.ac.uk 
Angela Last

\section{Re-reading Worldliness: Hannah Arendt \& the Question of Matter}

\section{Introduction}

Geography has greatly benefitted from a dialogue with materialism, whether of the 'historical' or of the 'new materialist' ${ }^{2}$ description. Historical materialism has sensitised geographers to the material dimension of inequality and socio-economic relations, whereas 'new materialism' has introduced a concern with the nonhuman for other than (purely) human ends. A key problem within materialism has always been the degree with which theories draw on scientific theories of matter or conceptualise the physical world. Are we materially set up to perform in a certain way, or do material processes not affect human culture in such immediately corresponding ways? How much do we or should we - read matter ${ }^{3}$ ?

Because of such preoccupations, materialism has been accused of leading to bad political consequences by default, whether in theory or practice. In geography, this fear of matter in politics has, for instance, manifested in the concern about a 'rematerialisation' of geopolitics, the latter having been brought on by the realisation that anthropogenic climate change and material destruction may somehow be connected to socio-cultural dynamics (Dalby, 2007; Weizman, 2010). By contrast, the advocacy of a 're-materialisation' of cultural geography has seen fewer obstacles, as the subfield has increasingly become regarded as apolitical. Despite their different levels of opposition to materialism, then, both cases reflect the cliché that matter is 'nothing' and has, or should have, nothing to do with politics (see Lenin, 1977: 190). According to this dismissive view, materialism continues to be attractive, because of its incredible possibilities for misuse, including the relegation of agency from individual humans to the nonhuman, and the openness of matter to any reading the reader may wish to project upon it.

Like historical materialism previously, new materialisms such as actor-network-theory, object orientated ontologies in general, enchanted and affective materialisms have been accused of leading to 'bad politics' (Fuller, 2000; Kirsch and Mitchell, 2004). Apparently forgetting populations that have been 'thing-ed for eons' (Ed Atkins in Apter et al, 2016: 7), they have attracted a reputation for being incapable of theorising crucial human (and even nonhuman) dynamics such as inequality, difference, violence and selfdestructive behaviour (Clark, 2011; Fuller, 2000: 11, 23; Harding, 2008: 122), topics that would warrant and validate their inclusion in the realm of political geography. Worse, inside and outside of academia, the new materialist theories continue to appear as 'feel 
good materialisms' that distract from the problematic alliances they make. Ostensibly seeking to inspire ways out of previous theoretical gridlocks by de-centering the human, they instead lead to questionable economic alliances with the entertainment and defence industry, in the form of banal art installations and coffee table books ${ }^{4}$.

Likewise, the 'darker', geophilosophy-affiliated new materialisms have been accused of leading to feelings of powerlessness or nihilism. What is a precariously permeable matter-energy manifestation to do? Manuel De Landa's 'call for a more experimental attitude toward reality and for an increased awareness of the potential for selforganisation inherent in even the humblest forms of matter-energy' (1997: 273) seems as overly optimistic as Ray Brassier's nod to 'species being' as a unifying identity 'that staves off the divisive identifications of individuality, ethnicity, nationality' (2014). For many politically minded geographers, the even less 'instructive' side of geophilosophy is even less useful, or rather trying too hard to be cool to be useful, with its apparent fetishisation of human extinction or certain types of matter, including fossils, obsidian, soil, rot, slime and other objects of gothic appeal (e.g. Negarestani, 2010; Woodard 2012). This preference for 'dark matter' has prompted the question whether 'geophilosophy' is merely an aesthetic project or a genuine challenge to dematerialised thought or to the 'cutesy reflexive things' of STS (Wyatt, 2014).

Because of such perceived failures, new materialisms have become regarded as either a poor successor to historical materialism - anaemic versions of the 'full-blooded' materialisms (Castree, 2002: 113) - or an outright antithesis. At the same time, historical materialism has also been diagnosed as a problem. In relation to the material conditions of life, it has been, for example, considered outdated for adhering to an decidedly inappropriate humanism (Whatmore, 1997), and for failing to deal with the shock of the nonhuman ability to upset human relations of production (Provost-Smith, 2015). Although there have been attempts to bring the two materialisms into dialogue with one another (Castree, 2002; Haraway, 2004; Kirsch \& Mitchell, 2004; Stengers, 2011; Swyngedouw, 1996), their politics continue to be perceived as mutually exclusive, because of their different approaches to economic production and social relations.

Despite their different appeal, both strands of materialism are not that dissimilar in their questions towards matter, for instance, in their drive to challenge established hierarchies and dynamics, and to move beyond individualisation of social problems. It is such 'common enemies' that make it worth persisting that there is, indeed, a basis for dialogue, despite the mutual mistrust about political value, aesthetics and effectiveness. There are, of course, multiple paths towards such a dialogue. The one pursued in this article, discontinuing the 'us versus them' polemic so far, is less interested in comparing and dismantling seemingly antagonistic examples of historical and new materialisms, but to ask a more fundamental question: Why do we need an attention to matter in geography - and in politics - in the first place? The answer, I hope, will help in drawing out one set of common sensitivities that may serve as a basis for dialogue. 
To tackle this question, I intend turn to a bit of an unusual place: the work of Hannah Arendt. Arendt may strike the reader as a curious choice for a discussion of matter: not only has she been conspicuously absent from geographical discussions of materiality (and even space), but also she is known as a strong critic of materialism and science. However, it is exactly this scepticism of matter and of de-individualisation that I would like to utilise in a 'devil's advocate' move. What makes Arendt's work particularly valuable, in my view, is the author's sensitivity to totalitarian tendencies that manifests in her strong distrust of materialism's deindividuating tendency - a move that always seems on the brink of leading to further dehumanisation. For Arendt, humans have material bodies that make them specifically human. This specificity is put into danger by materialisms that have a tendency to (re)unite human bodies it with other matter. Yet Arendt also acknowledges that it is impossible to entirely separate the human from matter: while she generally has a very negative attitude towards the encroachment of matter on human affairs, she is not interested in establishing simplistic boundaries either. She sets out careful rules where matter is appropriate and where not, for instance, in her conceptualisation of the public-private boundary.

Arendt is further interesting because of her persistent dialogue with the scientific developments of her time and with the cultural reactions towards them. Quantum mechanics, the theory of relativity and the space programme all feature in her analyses (2006: 48-9; 1998: 13). For instance, she maintained that the disjuncture between everyday human perception and scientific perception - starting with the discovery of heliocentrism - created a profound world alienation (2006: 54). Another relevant dialogue - amongst her many philosophical influences ${ }^{8}$ - took place with historical materialism. Like many authors of the interwar and postwar period, Hannah Arendt was dissatisfied with historical and dialectical materialism, but tried to constructively engage with it, despite her concerns about its role in the formation of totalitarian regimes.

Of particular interest for geographers is also Arendt's extensive use of the 'world' as a space and concept. Few people are aware that Hannah Arendt's famous book 'The Human Condition' was originally going to be called 'Amor Mundi: Love of the World' (Young Bruehl, 2004: xxiv). With the rise of new materialisms, the 'world' appears to have fallen out of favour as an unwieldy, amorphous entity that contains too many indistinctive human-nonhuman constellations to be of any use. More recently, however, an interest in the 'world' as a concept has resurfaced in recent debates in geography, which constructively seek to question its usefulness, both as a discipline-defining concept and as a wider theoretical and political intervention (Gibson-Graham, 2008; Shaw, 2010; Wainwright, 2010). Of particular interest in this paper is, as Ian Shaw phrases it, the 'attack on the gap between those that are included but do not belong to a world' (2010: 440). Here, material hierarchies play a key role.

Against the background of recent nature-culture debates, Hannah Arendt's distinction between earth and world may appear disturbingly unfashionable and unoriginal. As I will try to show in this article, this accusation is justified - in fact, it leads Arendt to some 
extremely alarming conclusions - but it is also not, because of the kind of analysis that it enables Arendt to perform: an analysis of the dynamics of dehumanisation. Further, the earth-world distinction is not only key to her intervention in materialism, but also to conceptualising 'worldliness' as a political attitude. In this article, 'worldliness' is being offered as a critical tool, but also itself subject to critique, in order to ask questions about the effect of exclusion of particular kinds of matter. What I attempt to show is how an Arendtian lens on materialism can not only draw out problems with current hostilities to materialism, but I can also identify common political concerns where dialogue can be established.

\section{Arendt's Division Between Earth and World}

In order to gain an idea of Hannah Arendt's position towards materialism, it is necessary to start with her key division between earth and world. This distinction is also crucial for understanding of her worldview, which is based on a balance between the two. While Arendt generally has a more nested vision of material spaces and encounters ${ }^{9}$, it is essentially her envisioned dynamic between earth and world that seems to give rise to these further distinctions. In Arendt's work, the earth represents the material realm, whereas the world represents what humans do with it - 'the man-made home erected on earth and made of the material which earthly nature delivers into human hands, [and which] consists not of things that are consumed but of things that are used' (1998: 134). However, the world is not just fabricated stuff, but also that which 'lies between people', an 'interspace' (1993, 3; 13). This separation of earth and world drives an interplay of forces that work both together and against one another, continuously shaping human life.

In this dynamic, matter stands for permanence and immortality, the material guarantee for the continuity of human life, while human life is characterised by fragility and plasticity (2006: 48; 1998: 134). This is, of course, not unproblematic, as geographers such as Nigel Clark have shown in their argument for a more volatile imaginary of nature (Clark, 2011). For Arendt, the idea of the natural permanence is important because it makes any desire to build a 'common world' possible: 'without this transcendence into a potential earthly immortality, no politics, strictly speaking, no common world and no public realm is possible' (1998: 55). If people assume that 'the world will not last', they withdraw from the public sphere. At the same time, Arendt also recognises the probabilistic essence of the 'processes in the universe and in nature' when she discusses the 'miraculous' origins of human life against all odds and the lingering presence of the miraculous within the everyday (2006: 168). As part of her analysis, she contrasts the 'shock of surprise' that humans feel at this realisation about their near-impossibility with the 'man-made' wonders and coincidences of human history (2006: 168-169). In both cases, she emphasises the accidental, the improbable that is present in anything from the depths of the cosmos to everyday life. However, she makes one tentative 
distinction: as beings capable of action, despite our incomplete control, we have a greater chance of influencing outcomes. Hence Arendt's work can be seen as a plea to be attentive to not only our limitations, but also to our means.

In fact, for Arendt, it is crucial that being human is not a fixed condition. Her criticism of Marx rests mainly on his apparent belief, despite his emphasis on material evolution, in an essential human nature 'for all time' (1973a: 456) ${ }^{10}$. As Sylvie Courtine-Denamy points out, Arendt was but one of the interwar thinkers who constructively criticised Marx. In Courtine-Denamy's comparison of Hannah Arendt and Simone Weil, she points out that both authors took Marx to account for his over-reliance on matter, as well as his utopian view of labour. For Weil, Marx replaced Hegel's 'hidden mind' with matter as the motor of progress (2006: 43). Matter became an automatic 'machine for manufacturing the good' (Weil, 2006: 164). For Arendt, too, not only was Marx' overreliance on matter problematic, but also any other conceptualisation that relied on matter as a motor of progress, such as in the reports of the scientists of her time. In her critique of science, she takes it to task for turning conscious human action and turning into a merely material process (Arendt, 2006: 274). It is human individuality that Arendt is concerned with, in terms of the agency of the individual to intervene and to create the conditions for good politics, something that is missing for her in Marx.

Regarding her emphasis on human individuality, it could be argued that Arendt follows a line similar to her contemporary Bataille and his argument for supplementing materialism with psychoanalysis ${ }^{11}$ : '[t] he basic error of all materialism in politics - and this materialism is not Marxian and not even modern in origin, but as old as our history of political theory - is to overlook the inevitability with which men disclose themselves as subjects, as distinct and unique persons, even when they wholly concentrate upon reaching an altogether worldly, material object' (Arendt, 1998: 183). To identify the human with history and the history with progress, as in Marxism, did not work for her (1973a: 456). For Arendt, as philosopher Vasti Roodt puts it: "human being is conditioned being. In other words, being human is not an absolute state, but conditional upon an encounter with - and thus an openness towards - the world and its limits' (Roodt, 2005: 119). It is also an openness towards matter, though of a different kind. Matter is what we are inevitably open to, since we are constituted by it. To gain humanity, we must constantly 'humanise' matter in order to produce a reality that sets us above being 'mere matter' (see Arendt 1993:16, 1998: 134). This is neither a process towards a uniform humanity, nor a fantasy of making the world more human, but a negotiation of the realisation that the world 'is not in the first place 'for us" (Roodt, 2005: 207).

This has the following consequence: while there is primordial matter, the matter that we, as humans, engage with, is never just primordial. In fact, Arendt mocks the 'Heisenberg man' - referring to the quantum mechanics pioneer - 'the man who will be less likely ever to meet anything but himself and man-made things the more ardently he wishes to eliminate all anthropocentric considerations from his encounter with the non- 
human world around him' (2006: 272). The drive towards finding out what things are without us remains pointless in her view - worldliness is, as Svetlana Boym puts it, only interested in the 'survival of the manmade world' (2009: 120). No matter how much things affect (or remain unaffected by) us, we need to make sense of them. This is not something that we can do by ourselves, but we need to make sense with others (Arendt, 1993: 31). It is these dynamics of sense-making, the constant threat of a loss of sense that we have to negotiate, that Arendt is concerned with. Matter cannot give us any answers or help us with sense-making. For the human world to function, as I will elaborate in the next section, matter has to be kept at bay.

\section{Arendt's Paranoia: Worldliness as Boundary Policing}

The most controversial of Arendt's views on matter and culture is perhaps her conceptualisation of politics. Her aim is to create a common world (and a politics) that transcends the material through pluralism. In itself, this is hardly controversial, yet as part of her critique of materialism, a number of issues arise. As established in the previous section, Arendt's process of sense-making is under threat from both the material and the cultural side. Here, Arendt's criticisms of Marxian materiality and of his related conception of labour and class stay central to her argument. For Arendt, as for Marx, material existence is associated with necessity. For Arendt, however, necessity negates pluralism, the key ingredient for political discourse. Material existence and material needs are levelling agents, rather than engines of diversity. Thus, in an Arendtian universe, it becomes incomprehensible that the labouring class is associated with the origin of change towards better politics and a more equal society. In her view, labour is so necessity-driven that the labourer is neither with the world nor in discourse with other people. The same goes for poverty in general: in another one of her examples, the poor, hungry masses of the French revolution were so governed by bodily needs and impulses that they could not produce pluralism and act politically. The result was a regime that was characterised by terror. In Arendt's view, physical needs and deficiencies turn people univocal and into something akin to an 'earth force' (1973: 59 \& 114): 'The cry for bread will always be uttered with one voice' (1973b: 114).

Arendt sees this excess of the 'unnatural growth of the natural' as a problem when labour has become the main emphasis of a society (Arendt, 1998: 47). An example would be today's mass casualisation of labour, a condition that puts people into a constant state of anxiety about basic necessities. For her, this leaves no room for care for the world. While this may sound like an elitist worldview where only those who managed to free themselves of labour, doubtlessly by taking advantage of those who do it for them, can take part in politics (e.g. Arendt, 1998: 120) - hierarchy tied to material dependence - it also allows her to explain mechanisms that continue to strategically disempower poor people. Conversely, Arendt also sees a threat coming from idleness, both through privileged freedom from labour and through mechanisation. At the other 
end of the spectrum, the world is threatened by the freeing of the body from necessity, a process that allows for an excessive growth and acceleration - in Arendt's view, a proliferation of the natural that is not kept in check any longer by constant labour (Arendt, 1998: 47).

This dual threat from the material, and from freedom from the material, also manifest as a problem in Arendt's process of sense-making: while only anthropocentrism can produce meaning (1998: 155), the human drive to instrumentalise devalues everything around them into 'a mere means to further ends' (1998: 156, 157). The 'world' and its plurality are in constant danger of annihilation by the material on the one hand (Zerilli, 1995: 171) and human instrumentality on the other. On the individual level, this translates into the 'sheer terror associated with mortality, with having a body' (Zerilli, 1995: 173; 188) and the fear of 'loss of symbolic mastery' (Zerilli, p. 174). Worse, projects that are non-instrumental are not necessarily inherently good. The totalitarian movements and their 'striking non-utilitarian traits' are a case in point (Arendt, 2006: 87).

Arendt's view of action is similarly shaped by a distinction between a homogenised or naturalised 'what' (e.g. 'women') and a plural 'who' (Arendt 1998: 181; see also Zerilli, 1995: 181; Honig, 141-142, 153): 'action without a name, a who attached to it, is meaningless' (Arendt, 1998: 181). Again, the body is part of a homogeneous, even dehumanised realm (material realm, social group), whereas the individual has a capacity for pluralism. The 'what' represents an attempt to stabilise meaning, whereas the 'who' has the opposite tendency (Zerilli, 1995: 187). In politics, the material body should not matter, but 'the world' that we give form to (see Honig, 1995: 142). In the words of Bonnie Honig, 'Arendt's actors do not act because of what they already are, their actions do not express a prior, stable identity; they presuppose an unstable, multiple self that seeks its, at best, episodic self-realisation in action and in the identity that is its reward' (Honig, 1995: 141).

At this point, it is, again, interesting to undertake a comparison between Arendt and Bataille's take on action. For both authors, action promises great things, but ultimately fails to live up to its potential. For Bataille, action is ultimately an illusion, an impotent fantasy, only transforming one's dreams 'on the level of the poorest reality' (1985: 226). This is because action is limited by material dynamics: it does not respect human dynamics and thus limits actors to 'follow that which exists' (1985: 226-227). In contrast to Bataille, Arendt views action as limited by human dynamics. The fact that we cannot escape anthropocentrism and, with this, attaching our own meaning, anything can be given meaning and can be put into 'meaningful action':

'The totalitarian systems tend to demonstrate that action can be based on any hypothesis and that, in the course of consistently guided action, the particular hypothesis will become true, will become actual, factual reality. The assumption 
which underlies consistent action can be as mad as it pleases; it will always end in producing facts which are then 'objectively' true"' (2006: 87).

However, despite being perversely volatile and 'in and by itself utterly futile', action has more potential, because it is unpredictable (2006: 60). Action ultimately cannot be directed, because of the many interactions it is subjected to. This is at once a failure and a possibility: while unpredictability prevents targeted action, it also creates space for new things to happen (op.cit.).

Interestingly, when it comes to handling matter or 'acting into nature', Arendt is more pessimistic. As human unpredictability is brought to bear on the natural realm and its laws, only great disaster can result (2006: 61). Again, Arendt is more concerned with the thoughtless instrumentalisation of things than with the romantic preservation of a pristine nature (2006: 63). As action increasingly dominates over thought and contemplation (2006: 62), Arendt cautions that more awareness needs to be created not only of the kinds of processes humans put into motion, but of the reasons for which they are put in motion (2006: 62-63). Here, worldliness enters as a cultural and political process that organises in the face of (material and social) limitlessness, passivity and apparent disorganisation (see Roodt, 2005: 56; Pitkin, 1998: 97). Worldliness expresses a desire to participate in the 'worldly space' and in the maintenance of humanity against a 'thoughtless' state (see Roodt, 2005: 53). The care of the world supersedes the care of the self (see Bowen Moore 1989: 143).

In some sense, worldliness can bee seen as a means of empowerment. As Roodt observes, one of Arendt's aims is 'to get away from the destructive notion that the world has - or should have - a moral meaning' (2005: 161). How the world was or is should not matter - it only leads to feelings of powerlessness (Roodt, 2005: 161). This also seems true for Arendt's 'earth'. To embrace worldliness is not to refrain from reading the world, or from reading matter, but to be attentive to readings and to wish to change them if they feel destructive of the world - in Arendt's case, it is the world as a space of free, pluralistic discourse that needs to be protected.

Thinking about worldliness in this way does not illuminate why concepts of matter are important as part of academic or political discourse. First of all, worldliness expresses a profound distrust of matter and a desire for order. Worldliness must be both about keeping material excess and social chaos in check. Maintaining one's place in the world requires constant vigilance, so that one does not end up 'worldless' or merely part of the natural world. Although worldliness constitutes the foundation of human activity in that it is about common care for 'what lies between people', there seems to be no room for safely admitting matter other than as an outside or interspace. 'To live together in the world means essentially that a world of things is between those who have it in common, as the table is located between those who sit around it, the world like every in-between relates and separates men at the same time' (Arendt, 1998: 52). The worst a person can do is to become (or designate fellow humans as) 'mere matter' - for Arendt, 
exemplified in the figure of Adolf Eichmann, the high ranking Nazi who she believed to have committed an 'administrative massacre' by blindly following orders.

At the same time, worldliness is in itself a concept that emerges from a particular conception of matter - a conceptualisation that enables, but, in Arendt's case, also prevents certain engagements with both the material and interhuman world that geographers are dealing with. In fact, its banishing of matter may make it more and not less liable to lead to dehumanisation. As I will try to show in the next section, in order not to lead to questionable outcomes, worldliness requires a sensitivity to the kinds of matter and the kinds of boundaries that are continuously being produced - matter is never just a primary, reliable externality. In the next section, I will try to specify how a reading through worldliness can help draw out particular problems as well as benefits of materialist readings, and I will also try to argue for a continued importance of an attention to matter.

\section{Worldliness' blind spots and their reproduction}

If worldliness represents a process of common sense-making of the world, particular kind of questions follow for materialist approaches. These concern the connection between matter and what kind of work particular readings of matter do in the 'worldly' realm: what kinds of violence are committed or what kinds of possibilities are opened in particular representations of matter? An analysis of Arendt's own reading of matter may serve as a warning and show why any application of 'worldliness' may need to be supplemented with other sensitivities to materialisation that have parallel antioppressive projects such as feminism and postcolonialism. Cleansing the 'world' of matter is not without consequences.

As Kathryn T. Gines and other feminist, especially black feminist philosophers have criticised, Arendt's distinction between the political and the social - the social being materially tainted - is highly problematic. In her preference of immaterial over material relations, Arendt ends up excluding pressing social issues from the political realm, such as 'economics, poverty, and racial oppression' (Gines, 2007: 47). Worse, Arendt's mistrust of material concerns poses barriers to who counts as an eligible participant in her world. Humans who, in Arendt's view, seem too much 'like a part of nature', such as tribal people (interestingly, she includes Africans and settlers in this category), have not created, and are thus unable to partake in 'a human world, a human reality' (1973: 192). Similarly, refugees and stateless people disturb the world of 'men', because they have become reduced to 'bare life', to what is given to any human being by birth (1973a: 301). They are particularly problematic, because they represent the breakdown of the natural/worldy boundary: the failure of political membership (citizenship) grounded in the natural category of birth (Borren, 2008: 215). Non-white people also present a problem, because they are seen as a racial category: their bodily visibility is too strong to overcome the designation of 'what'. 
Arendt's aversion to naturalisation was originally intended to prevent misuse, such as an unproblematic reference to naturalised communities (Zerilli, 2011: 129) or to land grabs by settlers (Honig, 2016). At the same time, however, it sanctifies misuse in that the physicality of certain forms of domination' is completely ignored (Cocks, 1995: 243): entities are discriminated against on the basis of being subject to material needs and oppression. Worse, oppression is naturalised and blamed on the oppressed themselves (Gines, 2014: 96, 111). While it could be argued that Arendt merely describes such destructive processes as 'the human condition' - after all, the groups that she mentions are being dehumanised and discriminated - the kind of recommendations that Arendt issues seem to affirm that she, in fact, upholds the ideal of the matter-less world, without looking at the Euro-centrism and racism of its origins (see Ferreira da Silva, 2007). As Arendt seeks to free politics from matter, her attention to destructive materialisation falters: rather than acting as a warning mechanism, it justifies oppressive hierarchies, including the destruction of the material world (including poor/non-Euronormative humans) as 'resource'. What kinds of pluralism and intersubjectivity are created here or being protected?

Yet an increased sensitivity to matter or its welcoming into the social or political realm does not automatically lead to less violent forms of ordering. In the materialist desire to perform 'mind as matter' to de-centre (new materialism) or re-centre (historical materialism) the human, the same problems as in Arendt's 'mind over matter' structure continue to appear. Especially new materialism and its desire to 'take [matter] seriously' (Braun \& Whatmore: 2010: ix) heavily relies on critiquing the split between nature and culture, usually blamed on René Descartes or European humanism (Braun and Whatmore, 2010: xi; Hawkins, 2010: 136; Latour, 2013; Whatmore, 1997: 45-46). This discomfort has resulted in a search for agency outside the human, as well as a redescription of the human as 'not only human' (e.g. Bennett, 2010: 116). Predictably, Arendt scholars have critiqued this move for its reliance on science or on nonhuman imaginaries to lead to positive political outcomes (Jones, 2013; Krause, 2015). There is anxiety that responsibility is being unhelpfully shifted through de-individualisation: an 'undifferentiated assignation of agency to matter' (Jones, 2013). As Sharon Krause writes: 'although the new materialism helps us understand the corporeal dimensions of individual agency and clarifies some dynamics of domination and oppression that are otherwise difficult to see, it often denies the importance of individuated identities and undercuts personal responsibility' (2015: 21, 22).

Generally, however, it is less the abnegation of individual responsibility that has come under fire, but the effects of the proposed new binaries. As Clive Barnett notes in his discussion of ontologies in geography, the rise of an 'ontological register of theoretical argument' has given rise to 'abstract delimitations', including discursive/material, human/nonhuman, representational/nonrepresentational, rational/'more-than-rational' (2008: 187). While the mistrust of rationality, especially Western rationality, enables a recognition of materiality and material relations - even an inclusion of it in the category 
of the 'social' - the human is often taken as homogenous matter and as always privileged, in these cases leaving a blindspot to inter-human inequality and already existing (violent forms of) objectification, for instance, to the ways in which people are forced to interact in destructive ways with other humans and nonhumans (White, 2013: 679). To many postcolonial scholars, this blindness to intersubjective interaction also manifests in the new materialist discourse itself, in the form of non-recognition of nonEuropean ontologies and/or the necessity to validate non-European ontologies through European and (white) American theorists (Sundberg, 2014; Todd, 2016; Tolia-Kelly, 2006; Tuhiwai Smith, 2012; Weheliye, 2014). Who is the 'we' that is not 'taking this stuff seriously'?

When it comes to 'nonhumans', something similar may be the case. As authors such as Graham Harman (2014) or Christian Thorne (2013) have argued, some political ontologies such as 'thing theory' are lacking an attention to specificities of relations or are merely adding characters to human power relations. This makes actors or objects essentially interchangeable (or subject-like) and ignores differences in distributions of agency. Papoulias and Callard (2010), by contrast, take issue with the kinds of matter that are being imported into certain new materialist theory. Often, what is being privileged is a matter that mirrors the authors' political project, for instance, a 'vision of nature with no fixity, one that can no longer be counted on to prop up calls to order, be they political or religious' (Papoulias and Callard, 2010: 36). This privileging, again, can lead to an 'environmental indeterminism' that cannot engage with the hierarchical selections at the human scale.

In this context, historical materialism, too, has come under scrutiny. Sylvia Wynter takes historical materialism to account for an over-reliance on re-organising production. For her, social hierarchies such as racism and sexism, inherent in the figure of 'Man' (humanity equated with the ideal of white bourgeois men), are not automatically contested through the proposed new handling of material necessities (Wynter in Wynter \& McKittrick, 2015: 41, 51). Denise Ferreira da Silva, too, points to the problematic link between 'the nature of individuals' and 'the material conditions determining their production', especially as the desired conditions are modelled on a particular European political and economic development (2007: 189, 191). While she appreciates the experiments with scientific universality and materiality to produce a different kind of ontology, she feels that historical materialism does not go far enough in its challenge, ending up with a familiar version of self-consciousness and selfdetermination (2007: 187).

What the above analysis attempts to show is that both Arendtian and many contemporary materialist approaches are subject to familiar problems stemming from philosophical hierarchies, even if they represent attempts to challenge them. In Arendt's case, worldliness is skewed towards the 'mind over matter' order, but it is also driven by the desire to re-order, and to acknowledge that a negotiation of materiality forms a necessary part of (human) life. While it is hard to agree with Arendt's obsession with 
human uniqueness and her problematic mode of individuation - despite its good intentions of overcoming the homogenisations of totalitarianisms, colonialism or social Darwinism - her interest in human materialisation is useful.

What becomes increasingly evident, no matter what type of theory we are using, is that it is necessary to be attentive to how we draw boundaries between, and how we selectively elevate, different forms of matter and material processes. In Arendt's case, it is the particular philosophical hierarchies that she draws on that pose a problem, namely, the imagination of a universal matter (and universal humanity) according to a particular tradition of European philosophy that has elevated a problematic relationship between interiority and exteriority to establish racial, gender and other hierarchies (see Ferreira da Silva, 2007 for an in-depth analysis ${ }^{13}$ ). The reliance on this tradition puts into perspective how much a difference the boundaries of a 'world' can make, as I will attempt to illustrate in the final part. Despite its shortcomings, the anti-totalitarian and anti-determinist origins of 'worldliness' can aid in the vigilance around the kinds of boundaries we are setting.

\section{Towards a different kind of worldliness?}

In The Human Condition, Hannah Arendt blames scientists for usurping the capacity for action in detrimental ways by 'extinguishing the time-honoured protective dividing line between nature and the human world' (1998: 324). In a different passage, Arendt points to the village walls that kept humans and nature apart in ancient and medieval times - a division that is being obliterated, in her opinion, to catastrophic effects by modern urban planning (2006: 279). For her, matter must be kept at bay at all costs for humans not to turn into things themselves. It is what turned Marxism into totalitarianism, modernity into a system that objectifies humanity and fascism into a popular ideology. Given Arendt's first-hand experience of sudden loss of a 'common world' and the rise of a new, strange and powerful science, capable of obliterating humanity, her conclusion is understandable: people cannot handle matter. However, given Arendt's description of what she is concerned about - alienation, dehumanisation, turn to totalitarian systems

- it could be argued that the problem she diagnoses is not an encroachment of matter, but a suppression of matter.

As an example, I would like to turn to Achille Mbembe's Critique de la Raison Nègre (in translation as Critique of Black Reason). In his discussion of the nonhuman, Mbembe presents what could be regarded as an inversion of Arendt's matter-sanitised world, set against the double (and intertwined) catastrophe of environmental destruction and human inequalities:

'And so it is all of humanity that bestows its name upon the world. In bestowing its name upon the world, it delegates itself to it and receives from it the confirmation of its proper place, singular but fragile, vulnerable and partial, at 
least with regard to other forces of the universe - animals and vegetation, objects, molecules, divinities, techniques, materials, the shaking ground, the volcanoes that light up, the wind and the storms, the waters that rise, the sun that erupts and burns and so on and so forth. So there is only a world through naming [nomination], delegation, mutuality and reciprocity.' (...)

'But if the whole of humanity delegates itself into the world and receives the final confirmation of its proper being as well as of its fragility, then the difference between the human and the nonhuman world is nothing more than a external difference.' (...)

'In opposing itself to the nonhuman world, humanity opposes itself.' (Mbembe, 2013: 258).

As with Arendt, the way this can be read is that, through our physical make-up, we cannot separate ourselves from anything in this world on the material level; we can only do this on the representational level. Mbembe's emphasis on the material condition of representation, however, prevents the possibility of separation, since such a separation amounts to self-destruction or, at least, self-harm ${ }^{14}$. Whereas Arendt would read selfdestruction as a consequence of a collapse of human-nonhuman distinctions, Mbembe argues, following Glissant's image of the 'tout monde' (a global plurality in interaction), that it is the border-maintenance that is our demise. For not only does it endanger our physical existence, but our political one as well, as our on-going exclusions strategically turn large sections of the global populations into objects: 'man-thing' (2013: 14), 'manmerchandise, man-metal, man-money' (2013: 258). Where Arendt's boundaries would almost certainly present a hopeless scenario of natural instability equalling political impossibility, Mbembe's attempted dissolution of boundaries presents a possibility to find a common world through the realisation of material commonality.

In theory, this is the point where historical and new materialisms seek to intervene by pushing for an admittance of matter into the sphere of politics, so that boundaries can be re-examined, shifted or dissolved. Normally, the quest of materialism has been to find other ways of relating, in the face of a being alienated 'both from nature and from a universal humanity' (Barta, 2007: 88). Materialisms can help through emphasising the shared materiality, as well as the link between social inequalities and environmental and eventual destruction. At the same time, both types of materialisms can benefit from a dialogue with 'worldliness'. Despite, or in some ways because of Arendt's phobia of matter, her concept raises important questions about individuality, plurality and the location of agency in the face of dehumanisation. Although materialisms are often aware of the risk of conflating deindividuation with dehumanisation, a sharpening of sensitivity towards this danger is useful. Of materialisms, Arendt's 'worldliness' seems to be asking: how can a different kind of plurality be brought into being that admits what has previously been excluded, and that does not end up contributing to harmful dehumanisations?

Some materialisms are better at negotiating the dehumanisation than others. Especially 
materialisms with feminist and anti-racist origins have a highly developed sensitivity for this problem, since they have emerged from an opposition to dehumanisation. Other materialisms are explicitly refusing an engagement with human inequality and difference, since these issues are regarded as a return to the harmful individualisation often framed as anthropocentrism - that needs to be overcome, tied to the illusion of human exceptionalism and individual agency. While there are different ways of dealing with dehumanisation, some of which embrace it as a strategy of destabilisation and disillusionment (see Colebrook, 2011: 14), the question of how individual agency remains. How much does the individual constitute a 'persistent possibility of... disruption and rearticulation'? (Butler, 1993: xvii) in the context of distributed (material) individuality?

Here, worldliness performs a sensitisation to two potential pitfalls of deindividuation. First, it cautions against a turn to de-individualisation that ends up being more individualist than whatever was the subject of critique. As Julie Torrant (2014) explains in her historical materialist critique of Grosz and Braidotti, new materialist feminisms are in danger of becoming 'forms of spiritualism' that turn critique of wider dehumanising structures into individual coping strategies or a reification of 'sense experience'. While one may not agree with all of her accusations, she draws out a pertinent issue that can potentially relate to all materialisms, given the difficulty to think beyond oneself. Even if we conceptually allow all of matter in, this 'matterism' (Ebert, 2009) does not automatically lead to an improved common world. In order for a 'care for the world' to be established, others need to be involved beyond their individual material presence.

Second, to materialisms that are seeking an expansion of what is human, an expansion of who or what can act, or a new kind of material hierarchy, 'worldliness' poses the challenge of how to negotiate the individual other than as a generic category. 'Worldliness' seems to both advocate for individuation (to prevent dehumanisation, to further agonistic relations) but also warns about the potential pitfalls of individuation (as a divorce from the rest of the world). Especially in geography, where we necessarily need to handle larger categories such as 'humans', 'animals', 'environment' to talk about current issues, thinking about materiality and individuality together can often be challenging. Moreover, thinking in such categories can often lead to the frustrating feeling of a lack of possibilities for change and intervention in what looks like an inevitable path. Here, using 'worldliness's' movement towards individuation can aid not only as a source of hopeful unpredictability, but also as a reminder of why we desire the deindividuation-drive of materialism even as we are fighting dehumanisation. It reminds us of the fact that, while matter is indifferent, we, as human individuals, together, can choose to materialise in different ways. 


\section{Acknowledgements}

I would like to thank Anja Kanngieser, Vasti Roodt, Mireille Roddier, Kathryn Yusoff, Dave Featherstone and especially the anonymous reviewers of this paper for their generous feedback and patience. I would also like to thank the participants in the Glasgow Geography HGRG seminar on feminist geophilosophy and geopolitics, and in the feminist geophilosophy sessions at the AAG 2015, for their helpful questions and encouragement.

\section{Bibliography}

Apter E, Atkins E, Avanessian A, Brown B, Bruno G, Bryan-Wilson J, Burnett D G, Chen M $Y$, Cole A, Cox C, Malik S, Demos T J, Dolven J, Doris D T, Draxler $H$, Falguières $P$, Galison P, Galloway A R, Haidu R, Harman G, Henrot C, Holmes B, Ingold T, Jones C A, Kitnick A, Lewitt S, Molesworth H, Nemerov A, Newman M, Papapetros S, Pfeffer S, Quack G, Ray C, Ritchie M, Rottmann A, Siegel A, Stakemeier K, Vierkant A, Wark M, Weizman E, Wood C S, Zhang G 2016 A questionnaire on materialisms. October 155: 4-5.

Arendt H, 2006 Between Past and Future (Penguin, Harmondsworth)

Arendt H, 1998 The Human Condition (University of Chicago Press, Chicago)

Arendt H, 1993 Men in Dark Times (Harcourt Brace \& Company, San Diego)

Arendt H, 1973a The Origins of Totalitarianism (A Harvest Book/Harcourt, New York)

Arendt H, 1973b On Revolution (Penguin, Harmondsworth)

Barnett C 2008 Political affects in public space: normative blind-spots in nonrepresentational ontologies. Transaction of the Institute of British Geographers 33(2) 186-200.

Barta T 2007 "On Pain of Extinction: Laws and History in Darwin, Marx and Arendt", in Hannah Arendt and the Uses of History : Imperialism, Nation, Race, and Genocide Ed. R King and D Stone (Berghahn Books, New York/Oxford) pp 87-108

Bataille G, 1985 Visions of Excess (Manchester University Press, Manchester)

Bennett J 2010 Vibrant Matter (Duke University Press, Durham NC)

Borren M 2008 Towards an Arendtian Politics of In/visibility. Ethical Perspectives 15(2) 213-237. 
Bowen Moore P, 1989 Hannah Arendt's Philosophy Of Natality (Macmillan, Basingstoke)

Boym S 2009 From Love to Worldliness: Hannah Arendt and Martin Heidegger. The Yearbook of Comparative Literature 55: 106-128.

Brassier R 2014 Wandering Abstraction. Mute 13 February 2014 http://www.metamute.org/editorial/articles/wandering-abstraction

Braun B, Whatmore S (2010) The Stuff of Politics: An Introduction, in Political Matter: Technoscience, Democracy, and Public Life Ed. B Braun and S Whatmore (Minneapolis, University of Minnesota Press) pp

Brown N 2011 The Speculative and the Specific: On Hallward and Meillassoux in The Speculative Turn: Continental Materialism and Realism Eds. L R Bryant, N Srnicek, G Harman (re.press, Victoria) 142-163

Butler J 1993 Bodies That Matter (Routledge, London/New York)

Castree N 2002 False Antitheses? Marxism, Nature and Actor-Networks. Antipode 34(1) 111-46

Clark N 2011 Inhuman Nature: Sociable Life on a Dynamic Planet (Sage, London)

Cocks J 1995 “On nationalism: Frantz Fanon, 1925-1961; Rosa Luxemburg, 1871 - 1919; and Hannah Arendt, 1906 - 1975", in Feminist Interpretations of Hannah Arendt Ed. B Honig (Pennsylvania State University Press, University Park, PA) pp 221-246

Colebrook C 2011 Matter Without Bodies, Derrida Today 4(1) 1-20.

Courtine-Denamy S 2000 Three Women In Dark Times : Edith Stein, Hannah Arendt, Simone Weil, Or, Amor Fati, Amor Mundi (Cornell University Press, Ithaca, NY)

Dalby S 2007 Anthropocene Geopolitics: Globalisation, Empire, Environment and Critique, Geography Compass 1(1) 103-118

De Landa M 1997 One Thousand Years of Nonlinear History (Zone Books, New York/London)

Deleuze G, Guattari F 2004 A Thousand Plateaus (Continuum, London/New York) Ebert T L 2009 The task of cultural critique (Urbana, III, University of Illinois Press) 
Engels F 1977 XXX in Marx, Engels, Lenin: On Dialectical Materialism Ed (Anonymous) (Progress Publishers, Moscow/Lawrence \& Wishart, London)

Ferreira da Silva D 2007 Towards A Global Idea Of Race. Minneapolis: University of Minnesota Press.

Fuller S 2000 Why Science Studies Has Never Been Critical of Science: Some recent Lessons on How to Be a Helpful Nuisance and a Harmless Radical. Philosophy of the Social Sciences 30(1) 6-32

Gibson-Graham J K 2008 Diverse economies: performative practices for other worlds, Progress in Human Geography 325 613-632

Guha M 2010 Introduction to SIMADology: Polemos in the $21^{\text {st }}$ Century in Collapse Vol IV Ed. R Mackay (Urbanomic, Falmouth) pp 323-378

Haraway D 2004 The Haraway Reader (Routledge, London)

Harding S 2008 Sciences from Below: Feminisms, Postcolonialities and Modernities (Duke University Press, Durham NC, London)

Harman G 2014 Bruno Latour: reassembling the political (Pluto Press, London)

Hawkins G 2010 Plastic Materialities, in Political Matter: Technoscience, Democracy, and Public Life Ed. B Braun and S Whatmore (Minneapolis, University of Minnesota Press) 119-138

Honig, B 2016 What Kind of Thing Is Land? Hannah Arendt's Object Relations, or: The Jewish Unconscious of Arendt's Most 'Greek' Text. Political Theory 44(3) 307336.

Honig B 1995 Toward an Agonistic Feminism: Hannah Arendt and the Politics of Identity, in Feminist Interpretations of Hannah Arendt Ed. B Honig (Pennsylvania State University Press, University Park, PA) pp 135-166

Jones K B 2013 New Materialism: From 'Why' and 'What' to 'How'. Hannah Arendt Center Blog. 8 April 2013. URL: http://www.hannaharendtcenter.org/?p=10073

Kirsch S, Mitchell D 2004 The Nature of Things: Dead Labor, Nonhuman Actors, and the Persistence of Marxism. Antipode 36(4) 687-705

Krause, S R 2015 Freedom Beyond Sovereignty: Reconstructing Liberal Individualism (Chicago University Press, Chicago). 
Kristeva J 2011 Hannah Arendt (Columbia University Press, New York)

Latour B 2013 An Enquiry into Modes of Existence (Harvard University Press, Cambridge Mass)

Lenin, V I 1977 How Certain 'Marxists' in 1908 and Certain Idealists in 1710 Refuted Materialism, in Marx, Engels, Lenin: On Dialectical Materialism Ed (Anonymous) (Progress Publishers, Moscow/Lawrence \& Wishart, London)

Loftus A 2012 Everyday Environmentalism: Creating an Urban Political Ecology (University of Minnesota Press, Minneapolis)

Marx K 2009 Economic and Philosophical Manuscripts in Marx's Concept of Man Ed E Fromm (Continuum, London) 71-152

Mbembe, A 2013 Critique de la Raison Nègre (La Découverte, Paris)

Negarestani, R 2010 Undercover Softness: An Introduction to the Architecture and Politics of Decay, in Collapse Vol IV Ed. R Mackay (Urbanomic, Falmouth) pp 257-303

Papoulias C, Callard F 2010 Biology's Gift: Interrogating the Turn to Affect. Body \& Society 16(1) 29-56.

Pitkin, H F 1998 The Attack of the Blob: Hannah Arendt's Concept of the Social (University of Chicago Press, Chicago)

Provost-Smith, P 2015 Presentation for Global Politics of the Anthropocene Seminar, New Centre for Research and Practice, 2 March 2015

Roodt V, 2005 Amor fati, Amor mundi: Nietzsche and Arendt on Overcoming Modernity, Stellenbosch University

Shaw I G R 2010 Sites, truths and the logics of worlds: Alain Badiou and human geography, Transactions of the Institute of British Geographers 35 431-442

Stengers I 2011 Wondering about Materialism in The Speculative Turn: Continental Materialism and Realism Eds. L R Bryant, N Srnicek, G Harman (re.press, Victoria) 368380

Sundberg J, 2014, Decolonizing posthumanist geographies Cultural Geographies Vol 21(1) 33-47

Swift S 2009 Hannah Arendt (Routledge, London) 
Swyngedouw E 2009 The city as hybrid: On nature, society and cyborg urbanisation. Capitalism Nature Socialism 7(2) 65-80

Thorne C 2013 To The Political Ontologists, in Dark Trajectories: Politics of the Outside Ed. J Johnson ([Name], Hong Kong) 97-121

Todd Z 2016 An Indigenous Feminist's Take On The Ontological Turn: 'Ontology' Is Just Another Word For Colonialism. Journal of Historical Sociology 29(1) 4-22

Tolia Kelly, D 2006 Affect - an ethnocentric encounter? Exploring the 'universalist' imperative of emotional/affectual geographies. Area 38(2) 213-217.

Torrant J 2014 It is time to give up liberal, bourgeois theories, including new materialist feminism, and take up historical materialist feminism for the $21^{\text {st }}$ century. The Red Critique 15 (Winter/Spring). URL:

http://www.redcritique.org/WinterSpring2014/historicalmaterialistfeminismforthe21stc entury.htm

Tuhiwai Smith, L 2012 Decolonizing Methodologies: Research and Indigenous Peoples (Zed Books, London)

Whatmore S 1997 Dissecting the autonomous self: hybrid cartographies for a relational ethics Environment and Planning D 15(1) 37-53

Weheliye A 2014 Habeas Viscus: Racializing Assemblages, Biopolitics, and Black Feminist Theories of the Human (Duke University Press, Durham NC)

Weil S 2006 Oppression and Liberty (Routledge, London)

Weizman E 2010 Political Plastic [Interview] in Collapse Vol IV Ed. R Mackay (Urbanomic, Falmouth) pp 257-303

White H 2013 Materiality, Form, and Context: Marx contra Latour. Victorian Studies 55(4) 667-682

Woodard B 2012 Slime Dynamics (Zero Books, London)

Wyatt S 2014 Comments at Closing panel: Dark Data, Disciplinary Histories and Future Directions, Knowledge/Value 5: Dark Data Workshop, University of Exeter, 16 December 2014.

Wynter S, McKittrick K 2015 “Unparalleled Catastrophe For Our Species? Or, to Give Humanness A Different Future: Conversations", in Sylvia Wynter: On Being Human As Praxis Ed. K McKittrick (Duke University Press, Durham NC) pp. 9-89 
Young-Bruehl, E 2005 Hannah Arendt: For Love of the World (Yale University Press, New Haven)

Zerilli L 1995 "The Arendtian Body", in Feminist Interpretations of Hannah Arendt Ed. B Honig (Pennsylvania State University Press, University Park, PA) pp 167-193

Zerilli L 2011 Hannah Arendt's 'Copernican Revolution', in Theory after Theory Ed. J Elliott and D Attridge (Routledge, London)

' I am aware that 'new materialism(s)' is a contested term that is resisted by many who are labelled as such. In this article, I use 'new materialisms' in the temporal sense: they include any contemporary attempts to re-envision materialism as something other than (just) historical materialism. I thus pull together theories as diverse as actor-network theory, agential realism, object orientated ontology, posthumanism etc.

3 'Matter' in this article is defined as that what is perceived as having physical substance. It is also assumed that matter is always 'read' or interpreted by humans, and that these readings are culturally or ideologically influenced, but can be contested.

${ }^{4}$ The impact of 'new materialism' on art and vice versa, has also recently been criticised in the latest 'A Questionnaire on Materialisms' special of the journal October, where Emily Apter, following Hito Steyerl, diagnoses an increasing expectation of the materially expanded artworld as 'sensory industry' (2016). In geography, there have also been instances where military funding or technologies were used as part of especially affect based research and engagement. This issue has mostly been raised by audiences at conferences, for instance, at the 'Feeling the Anthropocene: Air, Rock, Flesh' seminar (28 November 2014, University of Edinburgh) or the 'Plasticities' sessions at the RGS-IBG Annual Conference 2011.

${ }^{8}$ Arendt was influenced by thinkers such as Aristotle, Kant, Niezsche, Heidegger and Jaspers. The concept of worldliness is considered strongly influenced by Heidegger (e.g. on the question of meaning, care for the world, focus on the individual), but also differing from his philosophy (emphasis on public space and communication, theorization of difference and thinking, opposing visions and uses of nature, labour, art) (Kristeva, 2011: 197; Swift, 2009: 45-54).

${ }^{9}$ Vasti Roodt has summed up this nested vision as follows: 'Arendt investigates the interplay of conditions and capabilities whereby we have become - and are perpetually becoming - who we are. The particular conditions Arendt identifies are: the earth, which is the habitat in which we, along with all organic life, are able to "move and breathe without effort and without artifice" [Arendt, 1998: 2]; life itself, which is the biological process that is part of the general metabolism of nature, and which we share with all living things; worldliness, the condition of belonging to a world "which separates human existence from all mere animal environment" [Arendt, 1998: 2]; birth and death, or natality and mortality, understood as our appearance in and eventual disappearance 
from this human world; and finally, the condition of plurality: "the fact that men, not Man, live on the earth and inhabit the world" [Arendt, 1998: 7]' (Roodt, 2005: 119).

${ }^{10}$ Arendt also criticized Marx' reliance on utilitarianism: 'utility established as meaning creates meaninglessness' (Arendt, 1998: 154).

11 'Materialism will be seen as a senile idealism to the extent that it is not immediately based on psychological or social facts, instead of on artificially isolated physical phenomena. Thus it is from Freud, among others - rather than from long-dead physicists, whose ideas today have no meaning - that a representation of matter must be taken' (Bataille, 1985: 15).

13 As Denise Ferreira da Silva (2007) shows in her analysis of European intellectual history in philosophy and natural science, thinkers have gone against the core of their own theories to de-classify non-'Caucasians' as non-human.

14 In line with the nascent field of 'geophilosophy' and related philosophical discussions, this provocation could be taken further: how to think (or read) if thinking is selfdestructive at its core? I am thinking here of Manabrata Guha's question (following military strategist Carl von Clausewitz): 'How to think when thinking is chaotic at its core?' (2010: 333) 